\title{
ESTETIKA KOREOGRAFI SEBAGAI PENUNJANG KREATIVITAS SENI ANAK USIA DINI
}

\author{
Oleh: \\ Joko pamungkas \\ Joko anoman@yahoo.com \\ PAUD FIP Universitas Negeri Yogykarta
}

\begin{abstract}
Abstrak
Estetika koreografi merupakan sarana untuk berekspresi estetis secara kreatif pada anak dimanfaatkan untuk membina dan mengembangkan kreativitas anak pada usia dini. Estetika koreografi sebagai konsep pendidikan seni yang sesuai pada anak usia dini tidak mengajarkan bagaimana untuk untuk menari semata tetapi juga harus mengarah kepada pembinaan dan pengembangan kreativitas untuk mengangkat bakat dan potensi yang dimiliki oleh masing-masing siswa. Dalam pendidikan seni, anak dibebaskan untuk mengekspresikan apa yang ada dalam jiwanya baik itu melalui gerakan-gerakan tari. Yang bebas berekspresi membuat anak dapat menumbuhkan kreativitas anak untuk menciptakan sesuatu semakin berkembang.
\end{abstract}

Kata kunci: Estetik,koreografi AUD

\section{Abstract}

Aesthetics choreography is a means to express themselves creatively aesthetic in children used to foster and develop the creativity of children at an early age. Aesthetics choreography as appropriate concept art education in early childhood does not teach how to to dance alone but should also lead to the founding and development of talent and creativity to raise the potential of each student. In art education, children are free to express what is in his soul either through dance movements. Free expression makes the child can grow a child's creativity to create something growing.

Keywords : estetik, choreography AUD

PENDAHULUAN

Estetika merupakan istilah yang
identik dengan keindahan (Agus
Sachari.2002), dan keindahan itu lebih dekat dengan konsep seni pada umumnya dan seni pada khususnya identik dengan kesenangan, dan rekreasi. Saat kita mendengar kata seni maka yang mungkin muncul dalam benak kita adalah suatu karya seni entah berupa benda, musik, bangunan, lukisan atau benda-benda indah lainnya yang dihasilkan oleh seorang seniman yang tentunya sangat berbakat dan memiliki kreativitas yang tinggi. Dewasa ini seni tidak hanya merupakan suatu karya yang hanya bisa dinikmati saja, akan tetapi seni juga memiliki beberapa fungsi antara lain Fungsi Religi Keagamaan, Fungsi Komunikasi, Fungsi Rekreasi Hiburan,Fungsi Artistic, Fungsi Guna, Dan Fungsi Terapi Kesehatan

Estetika koreografi yang didalamnya memuat amteri tentang seni khususnya seni bagi anak usia dini mempunyai berbagai fungsi, fungsi itu mulai dikembangkan dan dimasukkan dalam bidang pendidikan. Dengan berbagai guna fungsi seni tersebut, seni dapat dimanfaatkan dalam bidang pendidikan dalam usaha pencapaian tujuan pendidikan. Khususnya alam dunia pendidikan seni untuk anak usia dini, materi seni seni untuk anak usia dini juga memberikan pengaruh penting terhadap 
perkembangan mental maupun fisik peserta didik. Bahkan, dengan pendidikan seni, perilaku peserta didik dapat terbentuk kearah yang lebih baik karena seni dapat mengenalkan nilai-nilai dan norma-norma yang ada dalam masyarakat kepada peserta didik.

Dalam seni, setiap orang dinilai memiliki kreatifitas dan kecerdasannya masing-masing. Seni dapat memfasilitasi setiap anak untuk menuangkan atau mencurahkan segala kreativitas berdasarkan kehendak masing-masing orang itu sendiri. Oleh karena itu, dalam artikel ini akan dibahas mengenai bagaimana Estetika koreografi menunjang atau mempengaruhi kreativitas anak usia dini dan membentuk atau mengembangkan kreativitas anak usia dini dengan memanfaatkan materi estetika koreografi.

\section{Difinisi estetika}

Secara umum estetika dalam bahasa yunani ialah Aeshesia yang membawa maksud hal - hal yang dapat diserap oleh panca indra atau lebih khusus lagi kepekaan manusia . estetika merupakan hakekeakt keindahan alam karya seni yang bermuara pada penciptaan karya estetika( joko sumarjo,2000)

\section{Estetika koreografi dalam Pendidikan Seni}

Kehidupan budaya manusia bersifat dinamik, terus berkembang dan berubah demi untuk mencapai kesempurnaan dalam kehidupan. Sebagai komponen dari kebudayaan baik seni maupun pendidikan mengalami pola perubahan yang sejalan dengan perkembangan pandangan hidup masyarakat. (Herawati, Ida Siti. Iriaji. 1998.) Pada dasarnya, konsep pendidikan seni ada dua macam, yang pertama yaitu konsep pendidikan seni yang berkaitan dengan aspek estetika koreografi sebagai ekspresi artistic dan kedua yaitu konsep esteika koreografi yang dikaitkan dengan tujuan pendidikan seni pada anak usia dini.

\section{Estetika koreografi sebagai gerakan reform}

Gerakan reform adalah usaha pembaruan di bidang konsep seni yang mengutamakan kebebasan ekspresi sebagai cara untuk memberi peluang kepada anak didik mengembangkan kemampuan yang ada pada dirinya. Gerakan ini bertujuan untuk mendewasakan anak didik bukan hanya pada segi intelektualnya saja, akan tetapi menghendaki agar anak belajar dari perbuatan aktif melalui kegiatan seni, maksudnya adalah anak dapat belajar dengan baik dan mendapatkan "pelajaran" dari apa yang telah dialaminya sendiri, bukan hanya melalui cerita, teori ataupun ceramah saja. Selain itu untuk melatih kedua tangannya supaya supaya syaraf dari otak kanan dan otak kiri terlatih dalam menjalankan fungsinya.

\section{Estetika koreografi sebagai bentuk apresiasi}

Konsep ini dipelopori oleh Alfred Lichtwart dan Konrad Lange, dengan pemikiran bahwa "persepsi" anak-anak kepada seni dan keindahan perlu dekembangkan melalui penghayatan langsung, baik melalui kegiatan menari dan bersosiodrama maupun kegiatan observasi, dengan melihat langsung obyekobyek seni seperti pentas, pameran, konser dan lainnya.

\section{Estetika koreografi sebagai Pembentukan Konsepsi \\ Konsep ini bermula dari pemikiran} bahwa menari adalah alat untuk mengungkapkan pikiran" yang dicetuskan oleh Walter Sargent. Menari adalah bahasa yang digunakan untuk melahirkan dan mengembangkan ide-ide. Mengekpresikan suatu obyek berarti menerjemahkan persepsi ke dalam bahasa gerak. Kegiatan menari merupakan 
kegiatan mental dan pikir yang dapat membentuk konsep. Konsep ini memandang seni pada proses kegiatannya yang terkait dengan kemampuan kognitif dan motorik halus dan kasar.

\section{Estetika koreografi sebagai Pertumbuhan Mental dan Kreatif}

Menurut konsep ini, anak adalah idenya, sedangkan seni adalah sarananya. Maksud dari konsep ini adalah, bahwa seni merupakan sarana bagi anak dalam proses pertumbuhan mental dan jiwa kreatifnya.

\section{Estetika koreografi sebagai Keindahan}

Konsep ini menyatakan bahwa seni identik dengan keindahan. Hasil seni yang indah didapatkan dari gerak gerak indah yang terseleksi.

\section{Estetika koreografi sebagai Seni sebagai Imitasi}

Menurut konsep ini yang dimaksud dengan kegiatan seni adalah kegiatan meniru gerakan alam, dan setiap hasil gerakan haruslah tiruan dari bentuk dan kejadian alam.

\section{Estetika koreografi sebagai sebagai Hiburan yang Menyenangkan}

Konsep ini berpendapat bahwa seni haruslah sesuatu yang menyenangkan dan dapat menghibur pengamat. Suatu karya disebut karya seni jika dapat dinikmati oleh pengamat dan pengamat dapat menangkap makna atau mengerti pesan/ide penciptaannya.

Materi seni pada anak usia dini, konsep seni khususnya estetika koreografi diarahkan pada pembentukan sikap, sehingga terjadi keseimbangan intelektual dan sensibilitas, rasional dan irasional, akal pikiran dan kepekaan emosi. Konsep ini mulai dikembangkan oleh Plato dalam tesisnya " Art should be The Basis of Education ". Konsep ini menempatkan seni sebagai materi, alat atau media dan metode yang digunakan dalam mencapai tujuan pendidikan.

\section{Pengertian Kreativitas}

Betapa pentingnya kreativitas bagi individu dan masyarakat. Di masa lampau, orang yang kreatif ditemukan hanya jika mereka telah membuat suatu produk yang orisinil. Padahal pengertian atau maksud dari kreativitas tidak hanya terbatas seperti itu saja. Kreativitas aalah kemampuan sesorang untuk menghasilkan komposisi gerak, produk tari atau gagasan apa saja yang pada dasarnya baru, dan sebelumnya tidak ada yang membuatnya. Ia dapat berupa kegiatan imajinatif atau sintesis pemikiran yang hasilnya bukan hanya perangkuman, tetapi mencakup pembentukan pola baru dan gabungan informasi yang diperoleh dari pengalaman sebelumnya dan pencangkokan hubungan lama ke situasi baru dan mungkin mencakup pembentukan korelasi baru. Hasil dari sebuah kreativitas dapat berupa produk seni, kesusastraan, produk ilmiah, atau mungkin bersifat procedural atau metodologis.

Unsur karakteristik kreativitas, yaitu antara lain :

1. Kreativitas merupakan proses, bukan hasil.

2. Proses itu mempunyai tujuan yang mendatangkan keuntungan bagi orang itu sendiri atau kelompok sosialnya.

3. Kreativitas mengarah pada penciptaan sesuatu yang baru, berbeda dan karenanya unik bagi orang itu, baik berbentuk lisan atau tulisan, maupun konkret atau abstrak.

4. Kreativitas muncul dari pemikiran divergen, lain halnya dengan konformitas atau pemecahan masalah sehari-hari yang timbul dari pemikiran konvergen.

5. Kreativitas merupakan suatu cara berpikir yang tidak sama dengan kecerdasan, yang mencakup kemampuan mental selain berpikir. 
6. Kemampuan untuk mencipta bergantung pada pengetahuan yang diterima.

7. Kreativitas merupakan bentuk imajinasi yang dikendalikan yang menjurus kearah beberapa bentuk prestasi.

Pada umumnya, kreativitas diartikan dengan daya atau kemampuan untuk mencipta, tetapi sebenarnya kreativitas memiliki arti yang lebih yaitu meliputi :

1. Kelancaran menanggapi suatu masalah, ide atau materi.

2. Kemampuan untuk menyesuaikan diri dalam setiap situasi.

3. Memiliki keaslian atau selalu dapat mengungkapkan sesuatu yang lain daripada yang lain.

4. Mampu berpikir secara integral, bisa menghubungkan yang satu dengan yang lain serta dapat membuat analisis yang tepat.

\section{Pembinaan Kreativitas melalui Estetika koreografi}

Anak usia Dini merupakan masa keemasan berekspresi kreatif. Kadar kreativitas anak masih sangat tinggi. anak dapat melakukan kegiatan berolah seni secara wajar dan spontan, karena daya nalar anak belum sampai membatasi keleluasaan untuk berkarya secara murni dan lugu. Ungkapan perasaan anak yang masih polos memungkinkan mereka untuk berekspresi secara wajar dan penuh spontan sehingga proses tersebut memiliki kebermaknaan bagi perkembangan mereka. Masa anak-anak merupakan awal berkembangnya kreativitas. Kreativitas tampak di awal kehidupan anak dan tampil dalam bentuk permainan. Seperti kita ketahui bahwa usia dini adalah usia bermain, kehidupan anak banyak dicurahkan untuk bermain. Bermain adalah mencoret, mencoreng, berteriak, meloncat, bergerak dan lainnya. Kegiatan bermain yang disenangi anak ini dapat diwujudkan dalam estetika koreografi gerak tari maupun gerak sehari hari. Kegiatan- kegiatan inilah yang diarahkan kepada pengembangan kreativitas.

Dengan demikian, berekspresi estetis secara kreatif pada anak dimanfaatkan untuk membina dan mengembangkan kreativitas anak pada usia dini. Pendidikan merupakan usaha dalam membantu anak mencapai kesuksesannya, demikian pula dengan estetika koreogarafi. Karena itu, segala cabang dalam seni dapat digunakan sebagai media dalam bidang pendidikan. Seni sebagai cara dan seni sebagai sarana. Seni sebagai sarana/media pendidikan adalah konsep pendidikan seni yang sesuai bagi anak-anak sekolah dasar. Sedangkan seni sebagai tujuan yang utama seringkali diselenggarakan di sekolah-sekolah seni atau disanggar. Oleh sebab itu, untuk pendidikan seni di anak usia dini, guru tidak mengajarkan bagaimana untuk menari tetapi juga harus mengarah kepada pembinaan dan pengembangan kreativitas untuk mengangkat bakat dan potensi yang dimiliki oleh masing-masing siswa. Dalam estetika koreografi, anak dibebaskan untuk mengekspresikan apa yang ada dalam jiwanya baik itu melalui gerakan-gerakan tari. Bebas berekspresi membuat anak dapat mengembangkan apa yang ada dalam dirinya, kreativitas anak untuk menciptakan sesuatu juga semakin berkembang.

Pada anak usia dini, anak mengalami masa keingintahuan dan perkembangan kognitif, afektif maupun psikomotor yang cepat. Perkembangan anak ini akan terhambat jika mereka "dibunuh" rasa keingintahuan dan kreativitas mereka. Kreativitas anak pada masa ini sangat beragam sesuai dengan tingkat kematangan dan perkembangan otak mereka. (Munandar, Utami. 2009) Oleh karena itu, untuk menunjang perkembangan kreativitas anak agar tumbuh optimal, estetika koreografi memegang peranan yang sangat penting yaitu sebagai sarana yang dapat memfasilitasi anak dalam mengekspresikan pikiran dan jiwa mereka. Tentu dengan bimbingan dan arahan dari 
guru sangat membantu dalam meningkatkan dan mengoptimalisasikan perkembangan kreativitas anak.

\section{PENUTUP}

Estetika koreografi pada anak usia dini diarahkan pada pembentukan sikap, sehingga terjadi keseimbangan intelektual dan sensibilitas, rasional dan irasional, akal pikiran dan kepekaan emosi. Karena pada masa usia dini, perkembangan mental dan fisik anak sedang dalam tahap maksimal sehingga untuk mengoptimalkan kreativitasnya maka estetika koreografi merupakan salah satu cara yang tepat untuk digunakan. Pada anak usia dini masih memiliki kejujuran dan kepolosan dalam berekspresi dan mengembangkan kreativitasnya. Oleh karena itu, estetika koreogri seharusnya dapat menjadi wadah atau sarana bagi anak untuk mengembangkan dan menuangkan kreativitasnya. Kebutuhan akan kreativitas bagi anak tidak hanya bagi kehidupan seninya saja tetapi juga dalam kehidupannya sehari-hari, kreativitas memiliki peranan yang sangat penting.

Kreativitas bukan hanya kemampuan untuk menciptakan tetapi lebih dari itu yaitu meliputi kemampuan membaca situasi, kemampuan beradaptasi dengan lingkungan, kemampuan membuat analisis yang tepat, serta kemampuan untuk menciptakan sesuatu yang baru yang lain dari pada yang lain. Maka dari itu, melalui estetika koreografi, anak dapat melatih dan meningkatkan kreativitasnya melalui kegiatan-kegiatan seni gerak yang sesuai dengan tujuan kegiatan-kegiatan yang dilakukan ini tetap menyenangkan bagi anak.

\section{DAFTAR PUSTAKA}

Agus Sachari.2002. Estetika: Makna, simbol dan ayat. Penerbit: ITB. BandungA.A.M Djelantik 